\title{
Life cycle carbon emissions inventory of brick masonry and light steel framing houses in Brasilia: proposal of design guidelines for low- carbon social housing
}

Inventário de emissões de carbono no ciclo de vida de habitações de alvenaria e light steel framing em Brasília: proposição de diretrizes de projeto para habitações de interesse social de baixo carbono

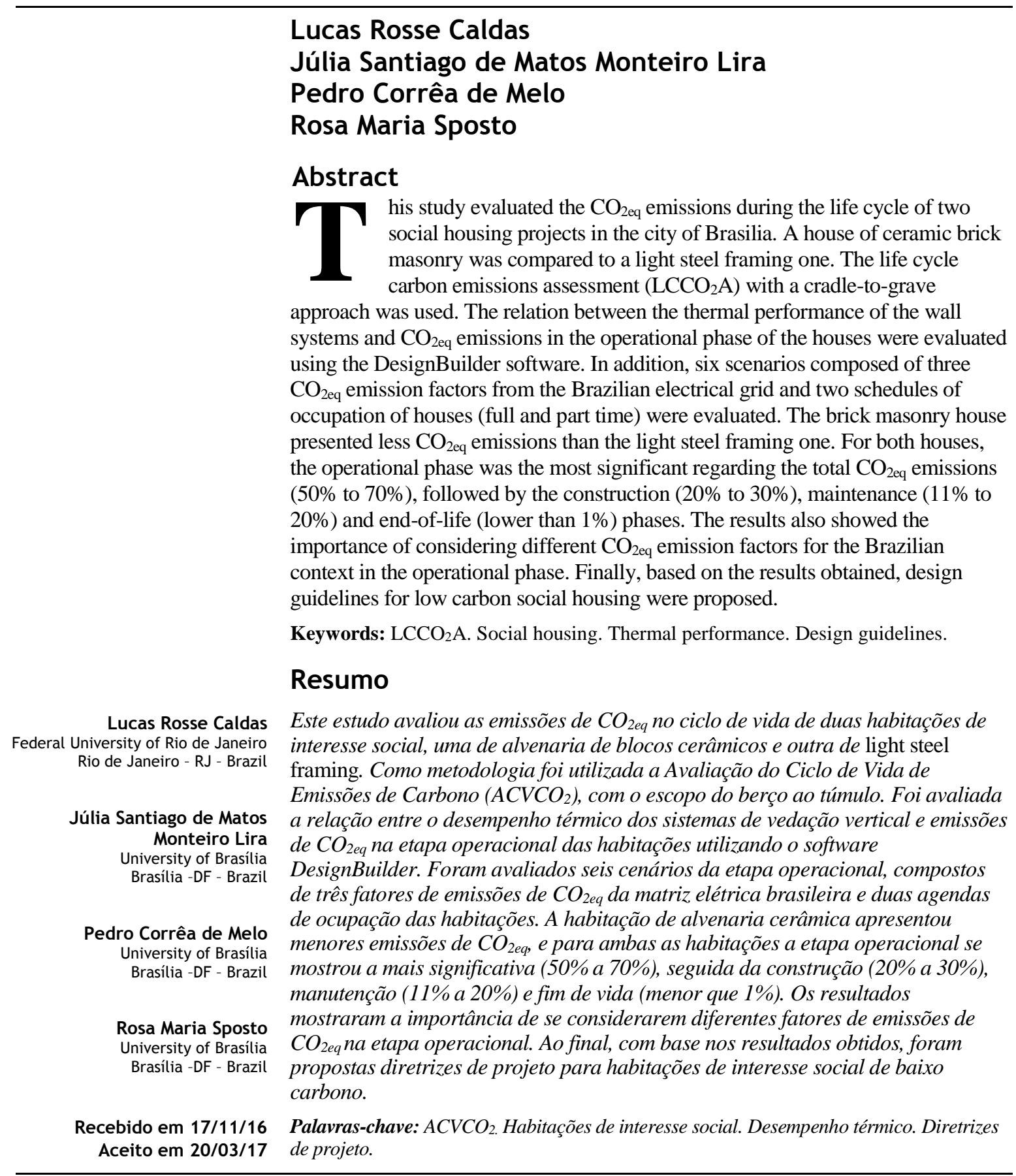

CALDAS, L. R.; LIRA, J. S. de M. M.; MELO, P. C. de.; SPOSTO, R. M. Life cycle carbon emissions inventory of brick 71 masonry and light steel framing houses in Brasilia: proposal of design guidelines for low-carbon social housing. Ambiente Construído, Porto Alegre, v. 17, n. 3, p. 71-85, jul./set. 2017. ISSN 1678-8621 Associação Nacional de Tecnologia do Ambiente Construído. http://dx.doi.org/10.1590/s1678-86212017000300163 


\section{Introduction}

In 2010 , buildings accounted for $32 \%$ of the total global final energy use and $19 \%$ of energy-related greenhouse gas (GHG) emissions (LUCON et al., 2014). The Brazilian residential buildings were responsible for $21 \%$ of the country's electricity consumption in 2015 (MINISTÉRIO..., 2016).

Brazil is a developing economy, a factor that influences the building sector. There is a housing deficit in the country and to overcome this problem, the Brazilian government has developed housing programs in recent decades such as "My house, My Life" (Minha Casa, Minha Vida) (PAULSEN; SPOSTO, 2013). Despite failures and criticism mainly related to the quality of the houses built, this program was responsible for the construction of thousands of new homes for people in need, thus alleviating the housing deficit in the country.

These social housing programs mainly used the brick masonry system. However, new building systems, which may be more rational and productive, are being considered, such as precast and prefabricated concrete, concrete walls and light steel framing. The latter has been imported from the USA and its use is becoming widespread in the country, due to higher productivity and the dry construction process (LIMA, 2016).

Nevertheless, it is necessary to define some environmental criteria, such as embodied energy and $\mathrm{CO}_{2}$ emissions, water consumption, waste and others, to help architects and engineers to specify more environmental sustainable systems (CARVALHO; SPOSTO, 2012).

According to Cabeza et al. (2014) and Chau, Leung and $\mathrm{Ng}$ (2015), the life cycle assessment (LCA), the life cycle energy assessment (LCEA) and the life cycle carbon emissions assessment $\left(\mathrm{LCCO}_{2} \mathrm{~A}\right)$ are some of the available and internationally widespread methodologies for environmental assessment in the building sector.

The life cycle assessment (LCA) evaluates all the resource inputs, including energy, water and material consumption, and environmental loads, including $\mathrm{CO}_{2}$ emissions, as well as liquid and solid wastes of a product or a process (INTERNATIONAL..., 2006). However, it has been observed that most of the research about LCA applied to buildings has focused on energy consumption and $\mathrm{CO}_{2}$ emissions. Within this context, more specific tools such as life cycle energy assessment (LCEA) and life cycle carbon emissions assessment $\left(\mathrm{LCCO}_{2} \mathrm{~A}\right)$ were developed.

LCEA and $\mathrm{LCCO}_{2} \mathrm{~A}$ are simplified versions of LCA. While the first one focuses only on the evaluation of energy inputs, the second focuses on $\mathrm{CO}_{2}$ emissions in different phases of a building's life cycle (CHAU; LEUNG; NG, 2015).

In Brazil, most studies of $\mathrm{LCCO}_{2} \mathrm{~A}$ focus on building materials. Campos, Punhagui and John (2011) estimated the CO2 emissions from the transportation of Amazon wood and evaluated the reduction of net carbon stock, due to this phase in the production process. Passuelo et al. (2014) evaluated the carbon footprint of an alternative laboratory-produced clinker. Saade et al. (2014) proposed a set of lifecycle-based indicators to describe eco-efficient building materials, presenting an important environmental database for Brazilian building materials, including $\mathrm{CO}_{2} \mathrm{eq}$ emissions. Borges et al. (2014) compared Portland cement and geopolymer concretes obtained from the alkaline activation of aluminosilicates. Santoro and Kripka (2016) evaluated $\mathrm{CO}_{2}$ emissions of concrete production, considering the material (binder, coarse aggregates, fine aggregates and steel) extraction and production stages used in the state of Rio Grande do Sul.

Paulsen and Sposto (2013) evaluated the energy consumption (embodied and operational energy) using the LCEA, during the life cycle of a typical social house in Brazil. Souza et al. (2016) used the LCA to compare three kinds of wall systems, made of concrete bricks, ceramic bricks and cast-in-place concrete. Atmaca and Atmaca (2015) applied the LCEA and $\mathrm{LCCO}_{2} \mathrm{~A}$ to compare two residential buildings in Turkey, one located in a rural area and the other, in the city. Cabeza et al. (2014) and Chau, Leung and $\mathrm{Ng}$ (2015) revised the state of the art related to the LCA, LCEA and $\mathrm{LCCO}_{2} \mathrm{~A}$ applied to the building sector.

Caldas (2016) and Caldas and Sposto (2016) compared one brick masonry and one light steel framing house in terms of thermal performance and embodied energy in Brasilia using the LCEA. The brick masonry house presented a better thermal performance and lower energy consumption during its life cycle. The present paper intends to continue these studies, though focusing on carbon emissions and analyzing different scenarios for the operational phase.

Although there are some studies in Brazil quantifying the energy consumption in a building's life cycle, there are fewer studies related to carbon emissions assessment, considering thermal performance and taking a cradle-to-grave approach.

Thus, through the $\mathrm{LCCO}_{2} \mathrm{~A}$ methodology, the aim of this study is to evaluate the $\mathrm{CO}_{2} \mathrm{eq}$ emissions during the life cycle of two social housing projects 
located in Brasília. Two different wall systems were compared: Brazilian conventional ceramic brick masonry and light steel framing, considering the buildings' entire life cycle, called cradle-to-grave in literature (construction, use and end-of-life phases).

Two important and innovative aims of this study were:

(a) the consideration of different operational phase scenarios, in terms of schedules of occupation of the buildings and different $\mathrm{CO}_{2} \mathrm{eq}$ emission factors from the Brazilian electricity matrix; and

(b) the proposal of some design guidelines for low carbon social housing based on the quantitative results of the $\mathrm{LCCO}_{2} \mathrm{~A}$ of buildings.

\section{Methodology}

\section{Functional unit, scope and description of the building}

The Functional unit (FU) for this study is a house located in Brasília - DF, with 4 residents (2 adults and 2 children), an internal floor area of $46 \mathrm{~m}^{2}$ and a 50-year lifespan (minimum value stipulated in the NBR 15575-1 (ABNT, 2013)). Brasília is situated in the Brazilian Bioclimatic Zone number 4 (NBR 15220-3 (ABNT, 2005)).

The house project consists of one living room, two bedrooms, one kitchen, one bathroom and one outdoor laundry area. There are three internal doors, two external doors and five windows. The solar orientation (facing the North) was chosen according to the worst situation related to thermal gains in the house, which was obtained in pre-simulations in the DesignBuilder. The west orientation for the bedrooms was chosen as presented in Figure 1. The foundation is not included in this study once it depends on the characteristics of the soil. Paulsen and Sposto (2013) adopted the same criteria.

The Brazilian conventional wall system is ceramic brick masonry with mortar plaster and reinforced concrete columns and beams, U-value: $2.5 \mathrm{~W} / \mathrm{m}^{2} . \mathrm{K}$. The light steel framing wall consists of galvanized steel frames with two oriented strand boards (OSB), one gypsum fiberboard in the internal area, one fiber cement board in the external area and an insulation layer of rock wool, U-value: $0.7 \mathrm{~W} / \mathrm{m}^{2} . \mathrm{K}$, as presented in Figure 2.

Table 1 below shows the cradle-to-grave scope, which includes construction (extraction, processing of raw materials and transportation of the building materials from factories to the site location), operation of the building, maintenance and end-oflife. The results are presented in terms of carbon dioxide equivalent $\left(\mathrm{CO}_{2 \mathrm{eq}}\right)^{1}$.

\section{Construction phase analysis}

The $\mathrm{CO}_{2 \mathrm{eq}}$ emissions in the construction phase were taken from the literature. For the light steel framing, Environmental Product Declarations (EPDs) were used. The waste of building materials during the construction process was considered. The construction working process, mainly performed manually, was not factored in in this study.

\section{Figure 1 - DesignBuilder model of the case study}

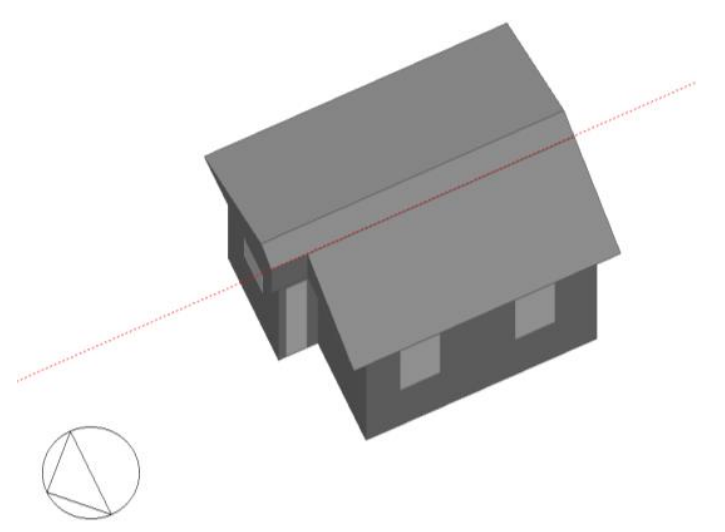

${ }^{1}$ For the $\mathrm{CO}_{2 \text { eq }}$ the following global warming potentials (GWP) were considered, according to IPCC (INTERGOVERNMENTAL... 2013): 1 for $\mathrm{CO}_{2}, 28$ for $\mathrm{CH}_{4}$ and 265 for $\mathrm{N}_{2} \mathrm{O}$. 
Figure 2 - Comparison between the two wall systems

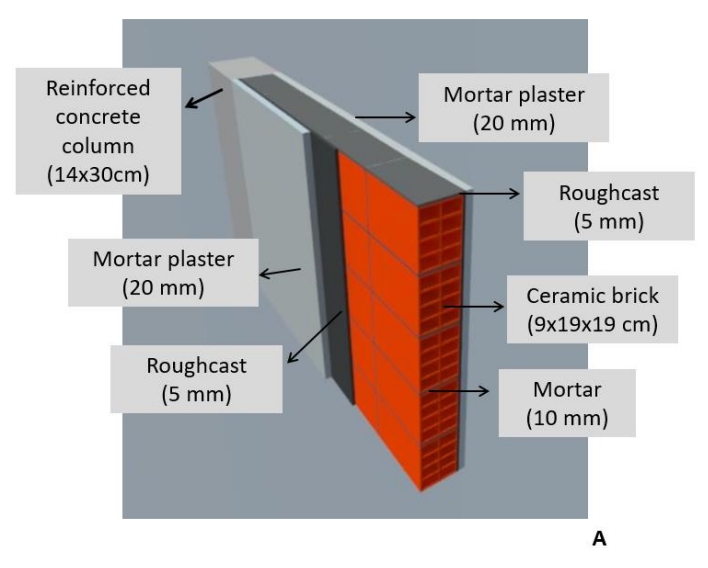

Brick masonry

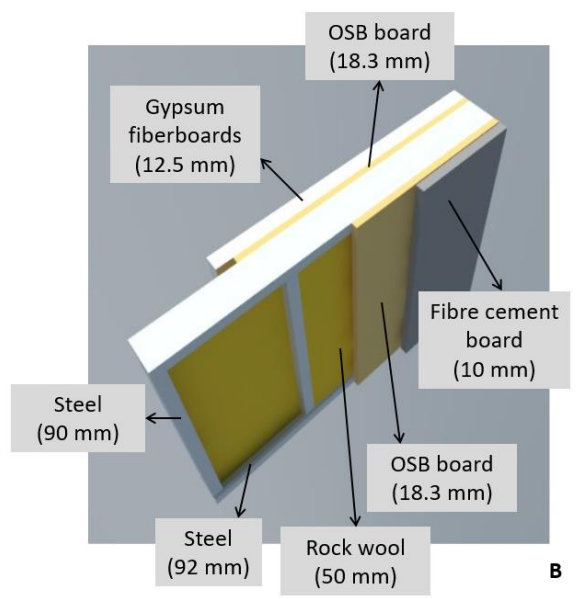

Light steel framing

Table 1 - Phases in the life cycle of the house

\begin{tabular}{|c|c|c|c|}
\hline Phases & Stages & Symbols & Description \\
\hline \multirow{2}{*}{$\begin{array}{l}\text { Construction } \\
\left(\mathrm{ECO}_{2} \mathrm{C}\right)\end{array}$} & $\begin{array}{c}\text { Extraction, processing of raw } \\
\text { materials }\end{array}$ & $\mathrm{ECO}_{2} \mathrm{E}$ & $\begin{array}{l}\mathrm{CO}_{2 \mathrm{eq}} \text { emissions of building materials } \\
\text { production }\end{array}$ \\
\hline & Transport & $\mathrm{ECO}_{2} \mathrm{~T}$ & $\begin{array}{l}\mathrm{CO}_{2 \mathrm{eq}} \text { emissions of transport from } \\
\text { factories to site location }\end{array}$ \\
\hline \multirow{2}{*}{ Use $\left(\mathrm{ECO}_{2} \mathrm{U}\right)$} & Operational & $\mathrm{ECO}_{2} \mathrm{O}$ & $\begin{array}{l}\mathrm{CO}_{2 \mathrm{eq}} \text { emissions of electrical } \\
\text { equipment and for cooking }\end{array}$ \\
\hline & Maintenance & $\mathrm{ECO}_{2} \mathrm{M}$ & $\begin{array}{l}\mathrm{CO}_{2 \text { eq }} \text { emissions of materials used in } \\
\text { maintenance }\end{array}$ \\
\hline \multirow{3}{*}{$\begin{array}{l}\text { End-of-life } \\
\left(\mathrm{ECO}_{2} \mathrm{EL}\right)\end{array}$} & Demolition/Deconstruction & $\mathrm{ECO}_{2} \mathrm{D}$ & $\begin{array}{l}\mathrm{CO}_{2 \text { eq }} \text { emissions of demolition or } \\
\text { deconstruction of house }\end{array}$ \\
\hline & Waste Transport & $\mathrm{ECO}_{2} \mathrm{Tw}$ & $\begin{array}{l}\mathrm{CO}_{2 \mathrm{eq}} \text { emissions of transport of waste } \\
\text { from site location to landfill }\end{array}$ \\
\hline & Waste disposal in landfill & $\mathrm{ECO}_{2} \mathrm{~L}$ & $\begin{array}{l}\mathrm{CO}_{2 \text { eq }} \text { emissions of activities for waste } \\
\text { disposal in landfill }\end{array}$ \\
\hline $\begin{array}{l}\text { Whole life } \\
\text { cycle }\end{array}$ & All stages & $\mathrm{ECO}_{2} \mathrm{TOT}$ & $\begin{array}{l}\text { Sum of } \mathrm{CO}_{2 \mathrm{eq}} \text { emissions of all stages } \\
\text { of the house life cycle }\end{array}$ \\
\hline
\end{tabular}

In Brazil, building materials are commonly transported by truck. In this case, the value of fuel consumption of $0.017 \mathrm{~L}$ diesel/t.km was adopted, as presented by Campos, Punhagui and John (2011). The full truckloads on the outbound route (from the factory location to the construction site) and half of the truckloads on the inbound route were recorded, therefore multiplied by a factor of 1.5 . According to IPCC (INTERGOVERNMENTAL..., 2006) and MMA (MINISTÉRIO..., 2013), one liter of diesel is equivalent to $2.63 \mathrm{~kg} \mathrm{CO}_{2 \mathrm{eq}}$, resulting, in the end, in a transport coefficient of $0.067 \mathrm{kgCO}_{2} / \mathrm{t} . \mathrm{km}$. The Google Maps app was used to calculate the transport distances, considering the shortest distance between the construction site and the building material producers (Table 2).

\section{Use phase analysis \\ Operational stage}

The operational energy and $\mathrm{CO}_{2 \text { eq }}$ emissions were divided into three parts: electricity used for equipment, liquefied petroleum gas (LPG) used for cooking and energy used for air conditioning (calculated in relation to the thermal performance of the buildings).

For the cooling simulation, the U-values used for brick masonry and light steel framing walls were $2.5 \mathrm{~W} / \mathrm{m}^{2} . \mathrm{K}$ and $0.7 \mathrm{~W} / \mathrm{m}^{2} . \mathrm{K}$, respectively. For windows, the U-value $5.6 \mathrm{~W} / \mathrm{m}^{2} . \mathrm{K}$ was used $(6 \mathrm{~mm}$ glass). Air conditioning appliances (split) were adopted for rooms in which people normally spend more time, such as the living room and the bedrooms. The cooling set point was fixed at 24.3 
${ }^{\circ} \mathrm{C}$ for these areas, according to the comfort zone of the city of Brasilia, defined by the neutral temperature equation presented by Pereira and Assis (2010). The machine efficiency (CoP) adopted was 2.8, a common value for this kind of houses in Brazil. Part and full time schedules of occupation for the living room and bedrooms were adopted to evaluate the minimum and the maximum potential energy consumption due to the air conditioning appliances. The part-time schedule adopted was from 5 p.m. to 12 a.m. for the living room, and 12 a.m. to 7 p.m. for the bedrooms.

EnergyPlus through DesignBuilder was used to evaluate the impact of variations of the external and internal walls on annual energy use and $\mathrm{CO}_{2 \mathrm{eq}}$ emissions of the building by dynamic thermal and energy simulation. After the simulation, the energy consumption for other electrical equipment (electric shower, refrigerator, TV, lighting, etc.) was $2414.17 \mathrm{kWh} /$ year.

The results found for air conditioning energy consumption were:

(a) brick masonry house with part- time schedules of occupation: $768.21 \mathrm{kWh} /$ year;

(b) brick masonry house with full-time schedules of occupation: $2228.78 \mathrm{kWh} /$ year;

(c) light steel framing house with part-time schedules of occupation: $1271.05 \mathrm{kWh} /$ year; and

(d) light steel framing house with full-time schedules of occupation: $3219.14 \mathrm{kWh} /$ year.

Table 2 - Data on building materials in the studied houses $\left(46 \mathrm{~m}^{2}\right)$

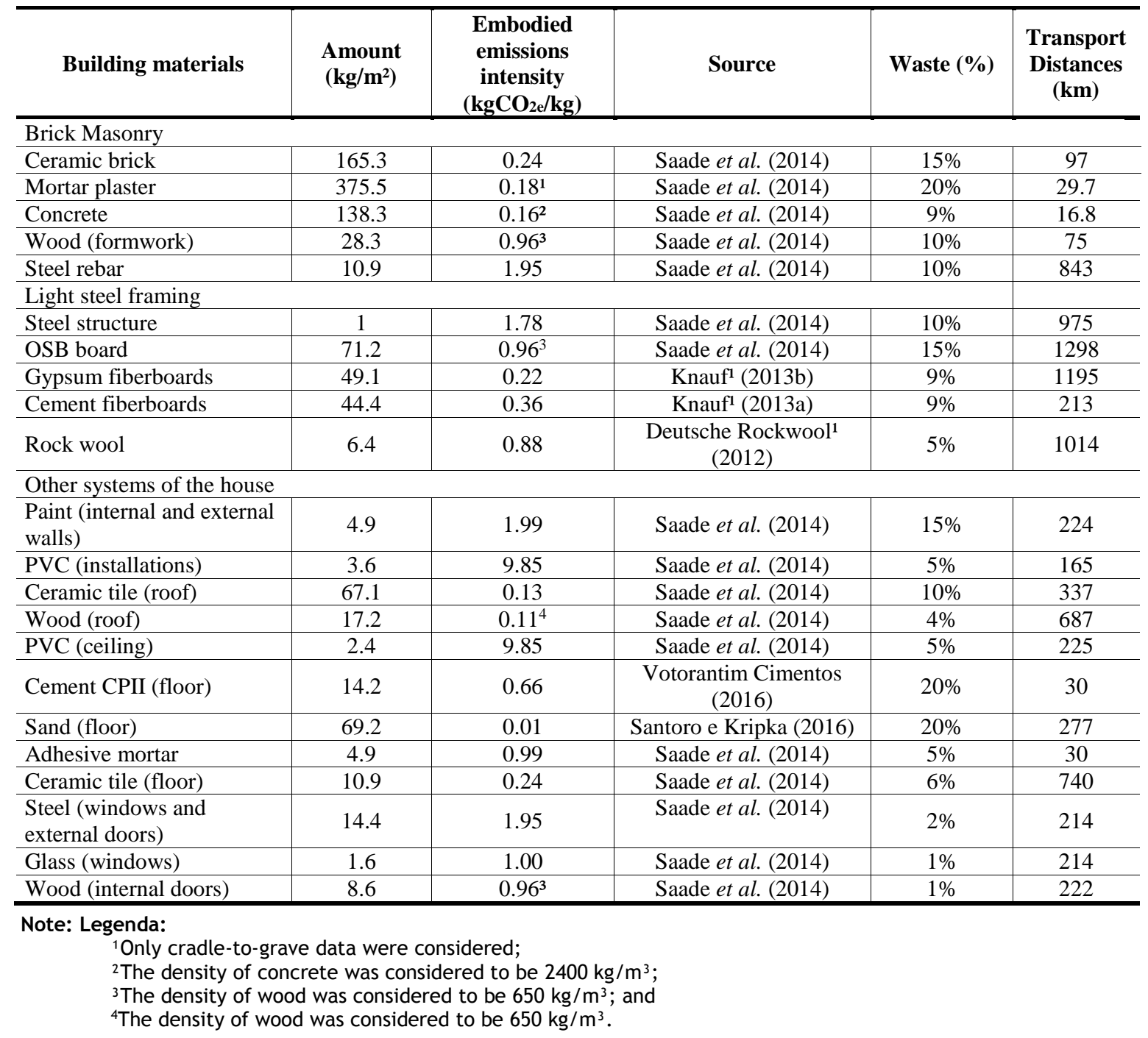


Three different values were used to estimate the $\mathrm{CO}_{2 \text { eq }}$ emissions of the Brazilian electricity matrix: (1) minimum value $\left(\mathrm{FCO}_{2 \mathrm{~min}}\right): 0.025 \mathrm{kgCO}_{2 \mathrm{eq}} / \mathrm{kWh}$; (2) median value $\mathrm{FCO}_{2 \text { med: }} 0.064 \mathrm{kgCO}_{2 \mathrm{eq}} / \mathrm{kWh}$; (3) maximum value $\left(\mathrm{FCO}_{2 \max }\right): 0.135 \mathrm{kgCO}_{2 \mathrm{eq}} / \mathrm{kWh}$, according to data collected by the Ministry of Science and Technology (Ministério de Ciência e Tecnologia - MCTI (MINISTÉRIO..., 2016)). As a result, there were six scenarios for the operational phase for each house:

(a) $\mathrm{FCO}_{2}$ min and full- time schedule of ocupation ( $\mathrm{FCO}_{2 \min }$ full);

(b) $\mathrm{FCO}_{2}$ min and part- time schedule of ocupation $\left(\mathrm{FCO}_{2 \min }\right.$ part);

(c) $\mathrm{FCO}_{2}$ med and full- time schedule of ocupation $\left(\mathrm{FCO}_{2 \mathrm{med}}\right.$ full);

(d) $\mathrm{FCO}_{2}$ med and part- time schedule of ocupation ( $\mathrm{FCO}_{2 \mathrm{med}}$ part);

(e) $\mathrm{FCO}_{2 \text { max }}$ and full- time schedule of ocupation ( $\mathrm{FCO}_{2 \max }$ full); and

(f) $\mathrm{FCO}_{2}$ max and part- time schedule of ocupation $\left(\mathrm{FCO}_{2 \max }\right.$ part).

The energy used for cooking comes from LPG, assuming a consumption of $13 \mathrm{~kg}$ of LPG per month. Also, a $2.98 \quad \mathrm{kgCO}_{2 \mathrm{eq}} / \mathrm{kg}$ ratio (INTERGOVERNMENTAL..., 2006) was adopted. The values of the operational stage were calculated for the stipulated 50-year lifespan of the house.

\section{Maintenance stage}

The $\mathrm{CO}_{2 \mathrm{eq}}$ emissions from maintenance for replacing used materials in the houses were analyzed. To calculate the maintenance intervals, data from the Brazilian building performance standard (ABNT, 2013) were used, resulting in replacement factors (RF). The same method was used by Paulsen and Sposto (2013), Atmaca and Atmaca (2015) and the other authors presented in Table 3.

The interior walls presented the largest difference when comparing the Brazilian RF and the mean value from other studies. A service life of 20 years was assumed for light steel framing and gypsum interior walls, resulting in a RF of 2.5. Whereas for the brick masonry system, a service life of 40 years for mortar covering was assumed, leading to a RF of 1.3. The transport of building materials and components used in maintenance were taken into account, adopting the same assumptions of the construction phase. The transport distance of replaced materials to landfills was assumed to be 20 kilometers from the building site during the maintenance phase. The demolition/deconstruction and disposal of these materials were allocated to the end-of-life phase. The end-of-life method is better detailed in the end-of-life phase section.

Table 3 - Replacement factor (RF) in different studies

\begin{tabular}{|c|c|c|c|c|c|c|c|c|c|c|}
\hline $\begin{array}{l}\text { Building } \\
\text { component }\end{array}$ & 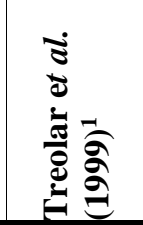 & 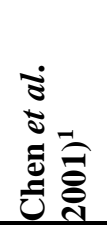 & 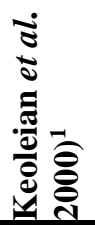 & 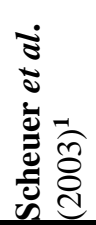 & 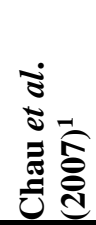 & 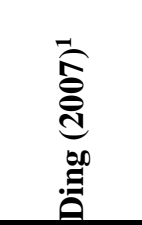 & 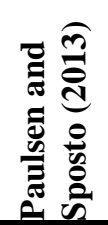 & 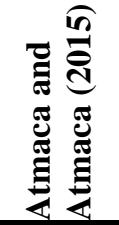 & 苞 & 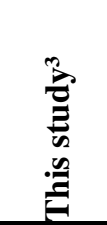 \\
\hline Country & Australia & $\begin{array}{l}\text { Hong } \\
\text { Kong }\end{array}$ & USA & USA & $\begin{array}{l}\text { Hong } \\
\text { Kong }\end{array}$ & Australia & Brazil & Turkey & - & Brazil \\
\hline $\begin{array}{l}\text { Walls } \\
\text { (Exterior) }\end{array}$ & 1.1 & 1 & - & 1 & 1 & 1 & 1.3 & 1.1 & 1.1 & 1.3 \\
\hline $\begin{array}{l}\text { Walls } \\
\text { (Interior) }\end{array}$ & 1.1 & 1 & - & 1 & 1 & 2.4 & 2.5 & 1.1 & 1.4 & $1.3-2.5$ \\
\hline Doors & - & 1.3 & - & 1.5 & - & $1.5-2$ & 1.3 & 2 & 1.6 & 1.3 \\
\hline Windows & - & 1.3 & 2 & 1.9 & - & 1.5 & 1.3 & 2 & 1.7 & 1.3 \\
\hline Roof & - & 1.3 & 2 & 3.75 & 2.5 & 2.4 & 2.5 & 2 & 2.6 & 2.5 \\
\hline Floor & 4 & 3 & 2.5 & 4.16 & 2.5 & 3 & 3.8 & 3 & 3.2 & 3.8 \\
\hline Paints & 8 & 5 & 5 & 15 & 5 & $6-8.6$ & - & 5 & 7.6 & 10 \\
\hline Ceiling & 2 & 2 & - & 3.75 & 2.5 & 4 & - & 3 & 2.7 & 3 \\
\hline
\end{tabular}

Note: ${ }^{1}$ Information obtained from Atmaca and Atmaca (2015).

${ }^{2}$ Average value from studies.

${ }^{3}$ Based on NBR 15575-1 (ABNT, 2013). 


\section{End-of-life phase analysis}

In the end-of-life phase, it was assumed that the building with brick masonry was demolished and the generated waste was transported to the nearest landfill, located 20 kilometers from the building site. The building with light steel framing was assumed to have been deconstructed and the assumed generated waste transported to the nearest landfill.

The end-of-life phase was divided into three stages:

(a) demolition/deconstruction;

(b) waste transport to the landfill; and

(c) waste disposal in the landfill.

Values of $0.00247 \mathrm{kgCO}_{2} / \mathrm{kg}$ were used for the demolition (ceramic brick masonry) and 0.000092 $\mathrm{kgCO}_{2} / \mathrm{kg}$ for deconstruction (light steel framing), based on Pedroso (2015) primary data. For the transport to the landfill, the same emission data were used for the truck transportation of building materials. For waste disposal activities performed in the landfill, a ratio of $0.37 \mathrm{~L}$ of diesel per 1 tonne of waste was assumed, an average value obtained from Bovea and Powell (2016) considering that one liter of diesel is equivalent to $2.63 \mathrm{~kg} \quad \mathrm{CO}_{2 \mathrm{eq}}$ (MINISTÉRIO..., 2013).

According to IAB (INSTITUTO..., 2016), currently in Brazil about $30 \%$ of all the steel produced comes from recycling. Usually, this recycled steel has already been accounted for in terms of the recycled content in steel production, using one of the approaches presented by Bergsma and Sevenster (2013). Therefore, the benefits of steel recycling in light steel framing were not considered. The only difference between steel and other materials is the third stage (3). Steel does not go to landfills; therefore it produces no emissions in this phase. Its transport distance to a recycling plant was assumed to be the same as that of other materials to a landfill.

\section{Design guidelines for low carbon social housing}

The design guidelines for low carbon social housing were given based on the quantitative results of $\mathrm{CO}_{2 \text { eq }}$ emissions during the houses' life cycle. Each phase of the life cycle was analyzed individually and, in the end, their impact in terms of total $\mathrm{CO}_{2 \mathrm{eq}}$ emissions was verified, and the guidelines were classified according to priority (high, medium-high, medium and low). Some suggested guidelines, based on the literature, were generic or not evaluated in this study. However, some points should be addressed in future studies.

Although this paper presents a case study with some particularities, such as the evaluation of thermal performance just for the city of Brasilia, the authors believe that these guidelines could be an important contribution for continuous research in the field of low carbon buildings.

\section{Results and discussion}

\section{Construction phase}

For the construction phase, values of $0.38 \mathrm{tCO}_{2 \mathrm{eq}} / \mathrm{m}^{2}$ and $0.32 \mathrm{tCO}_{2 \mathrm{eq}} / \mathrm{m}^{2}\left(\mathrm{ECO}_{2} \mathrm{E}\right)$ were found for the brick masonry and for the light steel framing houses, respectively. Comparing the $\mathrm{ECO}_{2} \mathrm{E}$ values, the difference was $16 \%$ with a lower value for the light steel framing system. A comparison of the different house systems in terms of mass and $\mathrm{ECO}_{2} \mathrm{E}$ is shown in Figure 3.

Figure 3 - Share of the house systems in mass and $\mathrm{ECO}_{2} \mathrm{E}$ for the construction phase
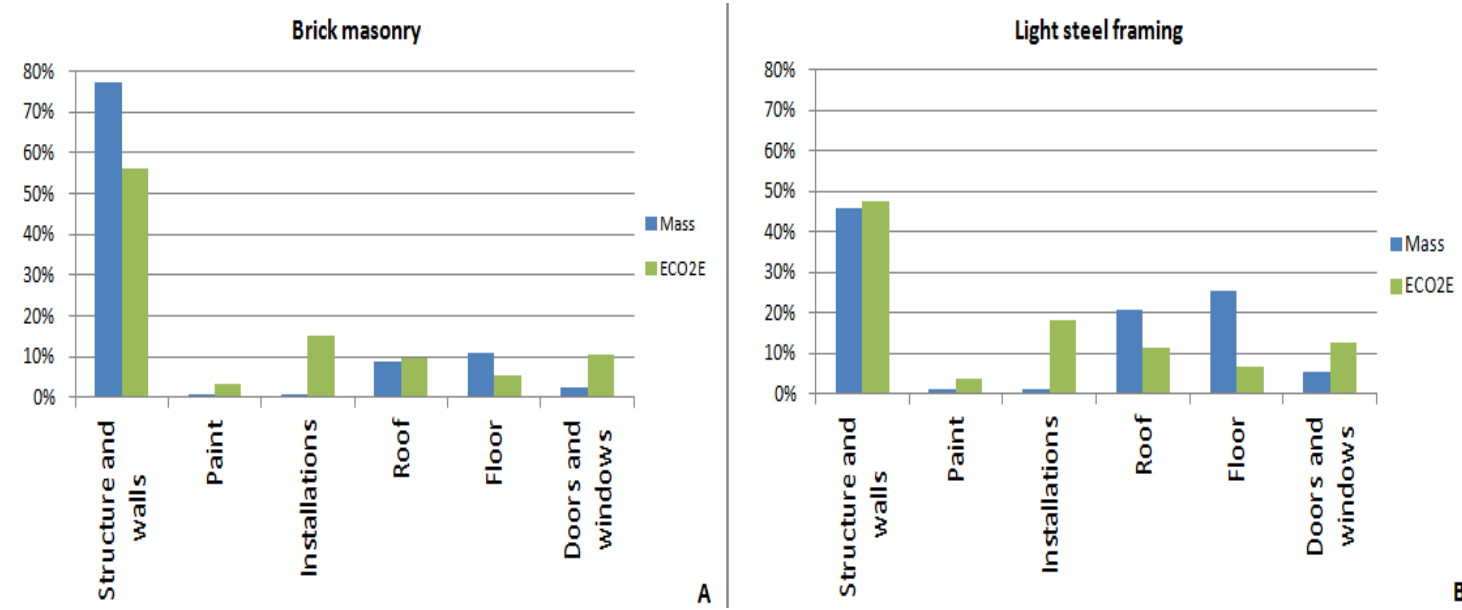

$\mathrm{ECO}_{2} \mathrm{E}$ - Extraction, processing of raw materials 
For both houses, the walls had the greatest mass (77\% for brick masonry and $46 \%$ for light steel framing) and $\mathrm{ECO}_{2} \mathrm{E}$ (56\% for brick masonry and $46 \%$ for light steel framing). These results show the importance of choosing an adequate wall system in a low carbon footprint social housing design. The share of materials and components of each building's wall system in terms of mass and $\mathrm{ECO}_{2} \mathrm{E}$ is presented in Figure 4.

The extraction and processing of raw materials were responsible for $97 \%$ of the total $\mathrm{ECO}_{2} \mathrm{E}$ for brick masonry and $94 \%$ for light steel framing. The transportation, on the other hand, played a small role, with $3 \%$ for brick masonry and $6 \%$ for light steel framing.

For the transport phase, the mass of the light steel framing was $57 \%$ less than the mass of the brick masonry. However, the results of $\mathrm{ECO}_{2} \mathrm{~T}$ show $0.011 \mathrm{tCO}_{2 \mathrm{eq}} / \mathrm{m}^{2}$ for brick masonry and 0.019 $\mathrm{tCO}_{2 \mathrm{eq}} / \mathrm{m}^{2}$ for light steel framing. The farther distances traveled by materials and components of light steel framing exceeded the impact of higher mass values of the brick masonry system. Therefore, to minimize the $\mathrm{CO}_{2 \mathrm{eq}}$ of the transport phase, it is important to specify during the design phase low mass materials and components located near the construction site.

\section{Use phase}

The use phase was composed of operational and maintenance phases. The operational $\mathrm{CO}_{2 \mathrm{eq}}$ emissions due to air conditioning ranged from 0.08 $\mathrm{tCO}_{2 \mathrm{eq}} / \mathrm{m} \quad\left(\mathrm{FCO}_{2 \text { min }}\right.$ partial $)$ to $0.68 \mathrm{tCO}_{2 \mathrm{eq}} / \mathrm{m}^{2}$ $\left(\mathrm{FCO}_{2 \max }\right.$ full) for the brick masonry house and 0.10 $\mathrm{tCO}_{2 \mathrm{eq}} / \mathrm{m}^{2}\left(\mathrm{FCO}_{2 \min }\right.$ partial $)$ to $0.83 \quad \mathrm{tCO}_{2 \mathrm{eq}} / \mathrm{m}^{2}$ $\left(\mathrm{FCO}_{2 \max }\right.$ full) for the light steel framing house. The total operational $\mathrm{CO}_{2 \mathrm{eq}}$ emissions (considering air conditioning, equipment and cooking) are presented in Figure 5.
The brick masonry presented a better thermal performance for the city of Brasília, due to the greater thermal capacity of the walls. According to NBR 15220-3 (ABNT, 2005) for Bioclimatic Zone 4 , it is more advantageous to use heavy walls in buildings. Hence, this masonry system was expected to present the best thermal performance. However, considering the growing interest in light steel framing systems in the Federal District region, this study evaluated the impact of the thermal performance of light steel framing on life cycle carbon emissions.

The $\mathrm{CO}_{2 \mathrm{eq}}$ emissions due to the electricity consumption for the six scenarios, including the air conditioning use, played a small role (14-23\%) in $\mathrm{ECO}_{2} \mathrm{O}$ for the $\mathrm{FCO}_{2 \min }$ and a greater role (48-62\%) for the $\mathrm{FCO}_{2 \max }$ (Figure 6).

The variation of $\mathrm{CO}_{2 \mathrm{eq}}$ emissions in this phase is due exclusively to the consumption of air conditioners because of the differences in thermal performance of the different facades of brick masonry and light steel frame buildings, considering the two schedules (part-time and full-time occupations) and the three $\mathrm{CO}_{2 \mathrm{eq}}$ factors from electricity $\left(\mathrm{FCO}_{2 \mathrm{~min}}, \mathrm{FCO}_{2 \text { med }}\right.$ and $\left.\mathrm{FCO} 2_{\max }\right)$. The cooking process was considered the same for both buildings.

The cooking process generates more $\mathrm{CO}_{2 \text { eq }}$ per energy. Considering $\mathrm{FCO}_{2 \max }$, its emissions (LPG) are almost twice the emissions from the electricity used for equipment. In relation to the $\mathrm{FCO}_{2 \mathrm{~min}}$, the difference is almost four fold. Therefore, one important strategy to reduce operational emissions when pursuing a low carbon social housing design, especially for a $\mathrm{FCO}_{2 \min }$ scenario, is to reduce the LPG use or substitute it for a less $\mathrm{CO}_{2 \text { eq }}$ fuel, for example, natural gas, since it emits less $\mathrm{CO}_{2 \mathrm{eq}}$ than the LPG.

Figure 4 - Share of wall building components in mass and $\mathrm{ECO}_{2} \mathrm{E}$ in the construction phase
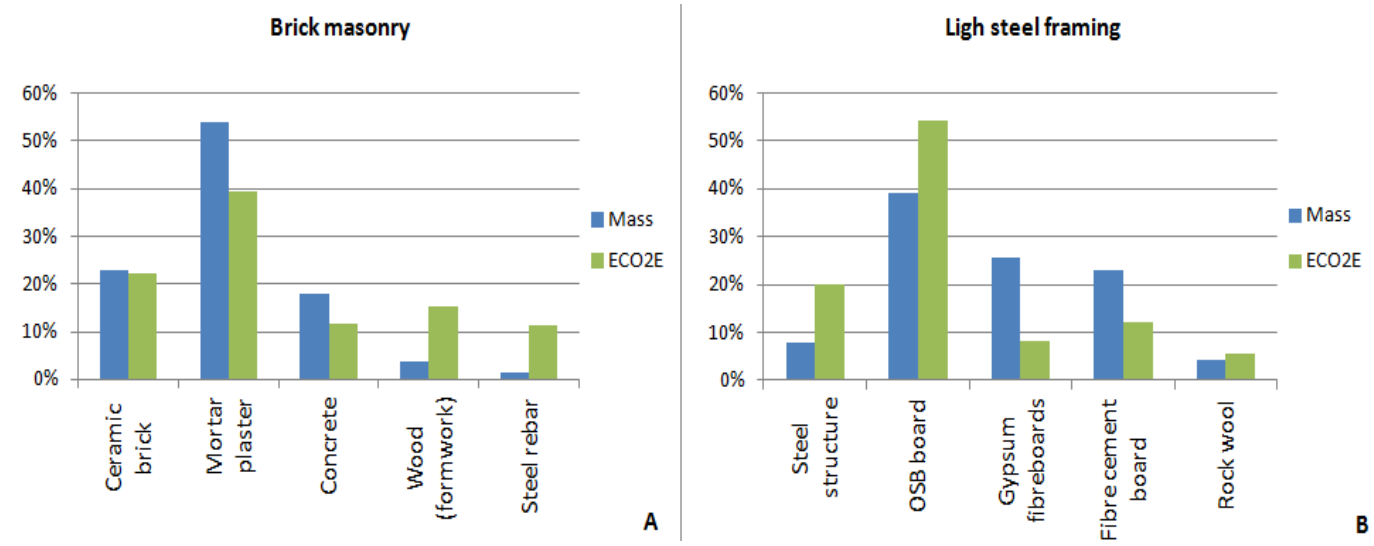

$\mathrm{ECO}_{2} \mathrm{E}$ - Extraction, processing of raw materials 
Figure 5 - Comparison of operational $\mathrm{CO}_{2 \text { eq }}$ emissions for the six scenarios
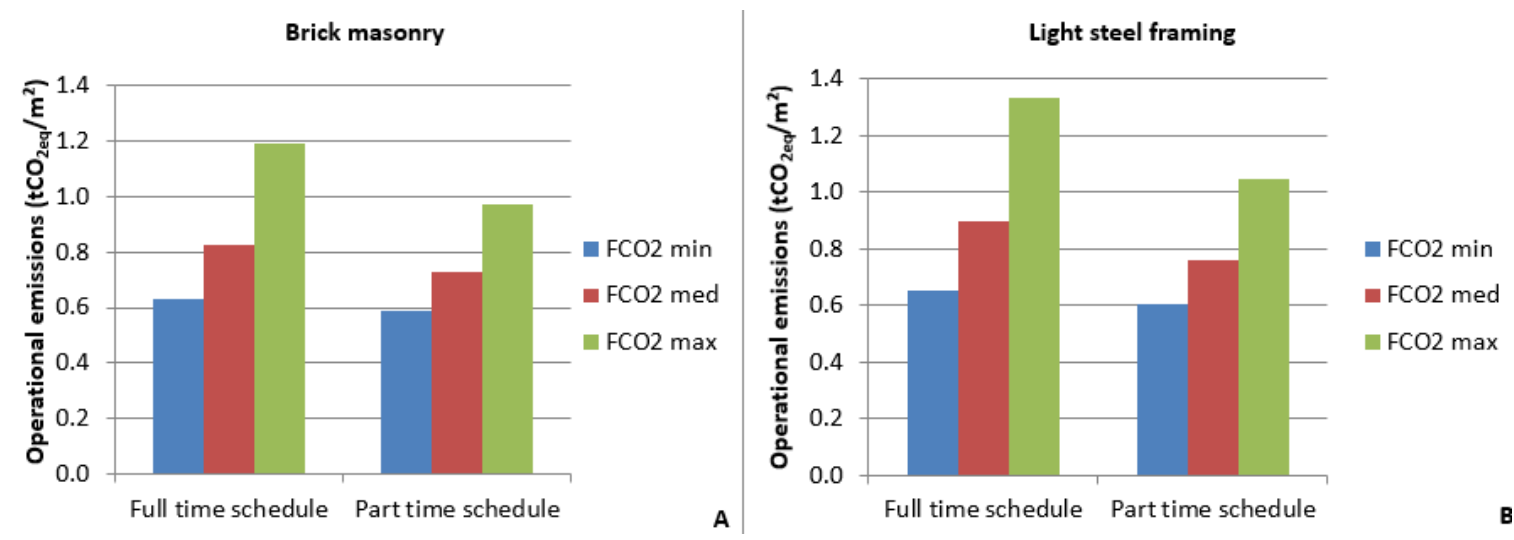

Figure 6 - Cooking, equipment and air conditioning share in the $\mathrm{ECO}_{2} \mathrm{O}$ phase

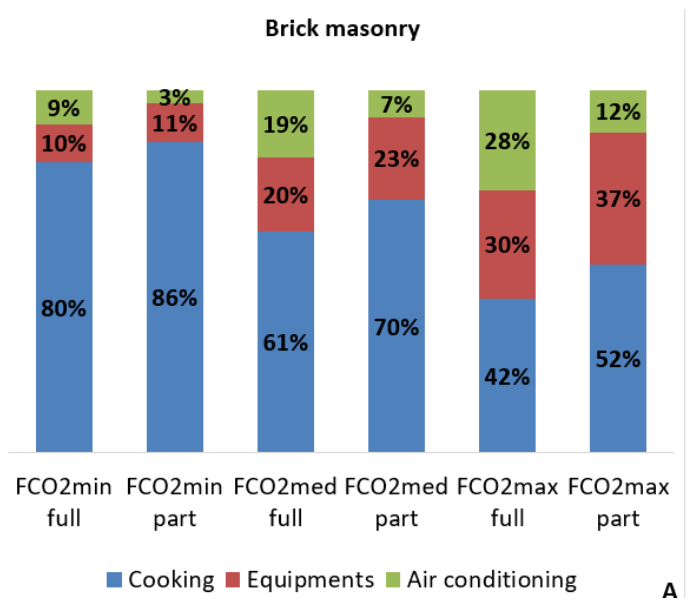

Regarding equipment, it is important to use pieces that consume less electricity. In Brazil, it is recommended to use label-A equipment as ranked by Procel. The electric shower accounted for the highest energy consumption and $\mathrm{CO}_{2 \mathrm{eq}}$, representing $35.5 \%$ of emissions of electrical equipment, requiring designer's attention for low carbon social housing projects. One alternative is to install solar panels for water heating, a suggestion that is encouraged in the "My House, My Life" Program. Nevertheless, it is necessary to consider the embodied $\mathrm{CO}_{2 \mathrm{eq}}$ due to material installation, replacement and end-of-life during the building's life cycle.

Concerning the maintenance phase, the results of $\mathrm{ECO}_{2} \mathrm{M}$ for brick masonry and light steel were 0.19 $\mathrm{tCO}_{2} / \mathrm{m}^{2}$ and $0.24 \mathrm{tCO}_{2} / \mathrm{m}^{2}$, respectively. The larger values for the light steel framing house are due to the gypsum board substitution (20 years), and OSB board and rock wool substitution (30 years); meanwhile, the mortar and plaster were considered to have a service life of 40 years. The mass and $\mathrm{ECO}_{2} \mathrm{M}$ for the houses are compared in Figure 7.

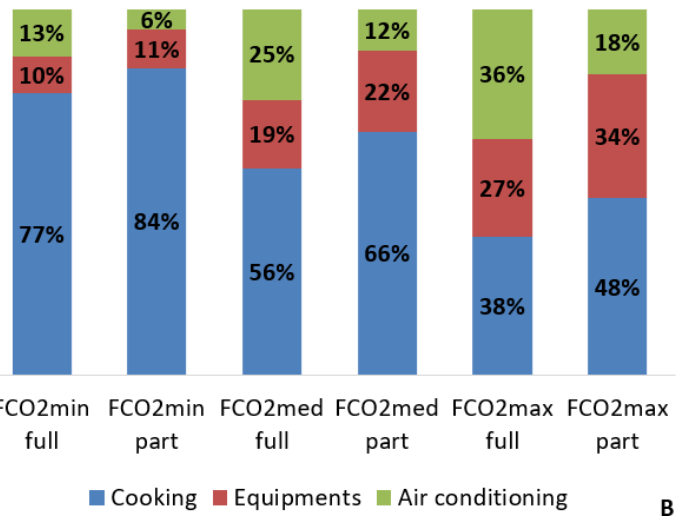

The paint system was responsible for great $\mathrm{CO}_{2 \mathrm{eq}}$ emissions because of the low service life considered (5 years) and the high value of embodied $\mathrm{CO}_{2 \text { eq }}$ of paints, $1.99 \mathrm{kgCO}_{2 \mathrm{eq}} / \mathrm{kg}$. Therefore, to minimize the impacts of the maintenance phase it is important to specify, during the design phase, materials with low values of $\mathrm{CO}_{2 \mathrm{eq}}$ emissions and high durability.

\section{End-of-life phase}

For the end-of-life phase, 0.0063 and $0.0024 \mathrm{tCO}_{2 \mathrm{eq}}$ per $\mathrm{m}^{2}$ were recorded for the brick masonry and the light steel framing houses, respectively (Figure 8). The end-of-life phase considered in this study consisted of demolition (for brick masonry) and deconstruction (for light steel framing), as well as waste transportation and disposal activities in the landfill. Assuming that transport distances were the same for the brick masonry and the light steel framing houses, the difference in the results reflected the mass of the wall systems and the processes used in demolition and deconstruction.

The deconstruction process of the light steel framing resulted in less $\mathrm{CO}_{2 \mathrm{eq}}$ than de demolition process of brick masonry. The waste transport was 
influenced by the mass and distances to the landfill. In addition, the waste disposal was influenced by the mass of waste. Therefore, in order to decrease carbon emissions of the end-of-life phase, it is important to prioritize a deconstruction process over demolition, have material wastes with lower masses and choose shorter distances to disposal, reuse or recycling plants from the building location.

\section{Overall life cycle balance}

The results of $\mathrm{ECO}_{2} \mathrm{TOT}$ for brick masonry and light steel framing houses for the six scenarios are presented in Figure 9.

Figure 7 - Share of the house systems in mass and $\mathrm{ECO}_{2} \mathrm{M}$ for maintenance stage

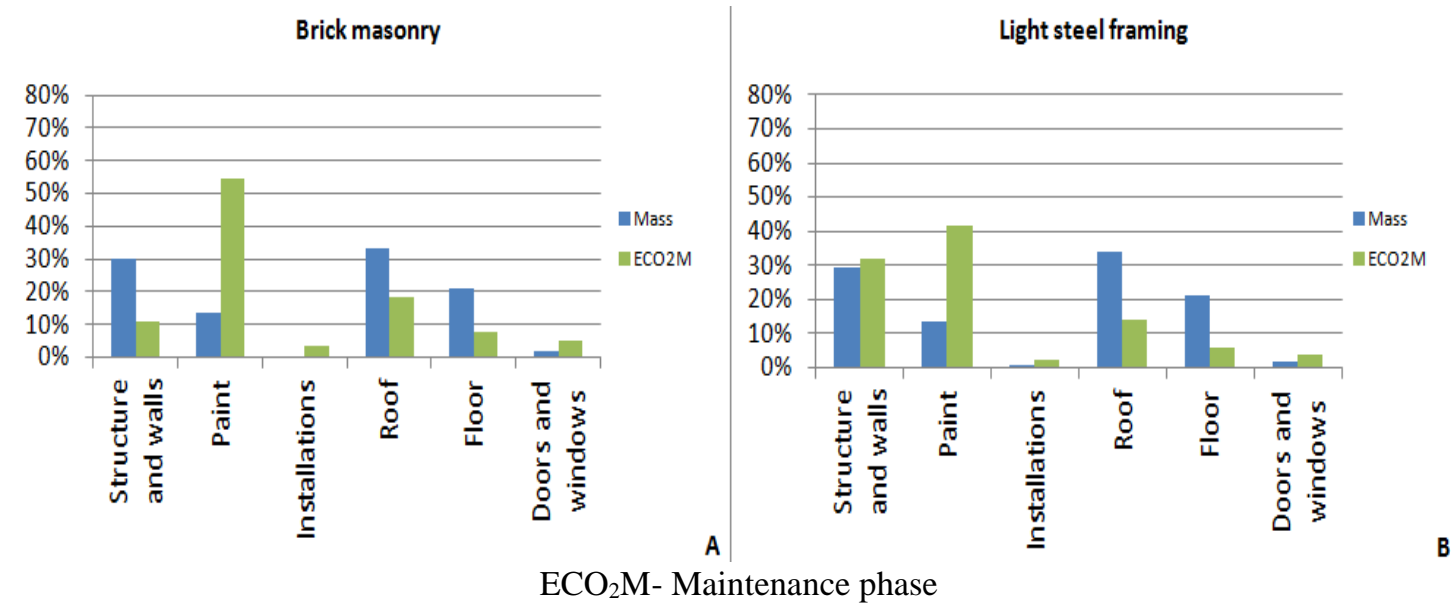

Figure 8 - Comparison of end-of-life $\mathrm{CO}_{2 \text { eq }}\left(\mathrm{ECO}_{2} \mathrm{EL}\right)$ emissions

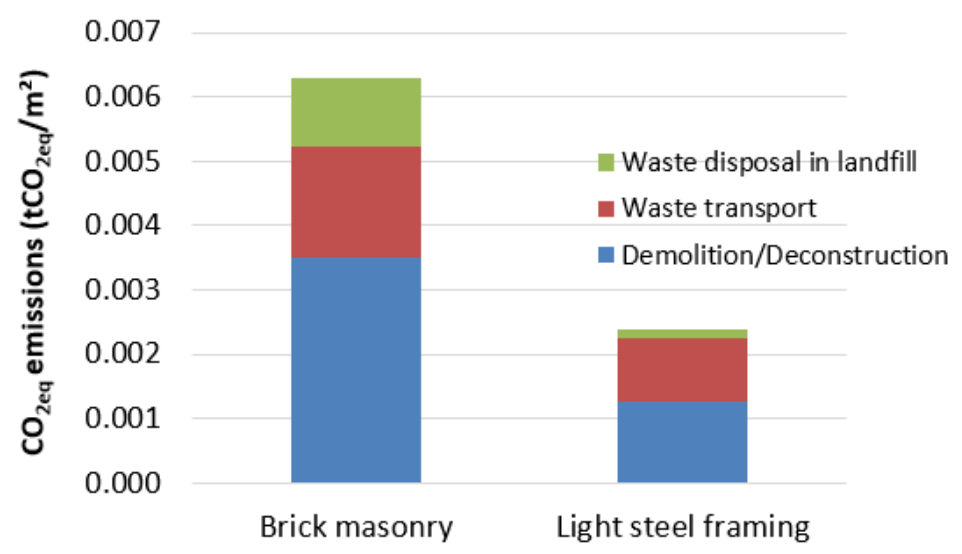

Figure 9 - Total life cycle $\mathrm{CO}_{2 \text { eq }}$ emissions assessment
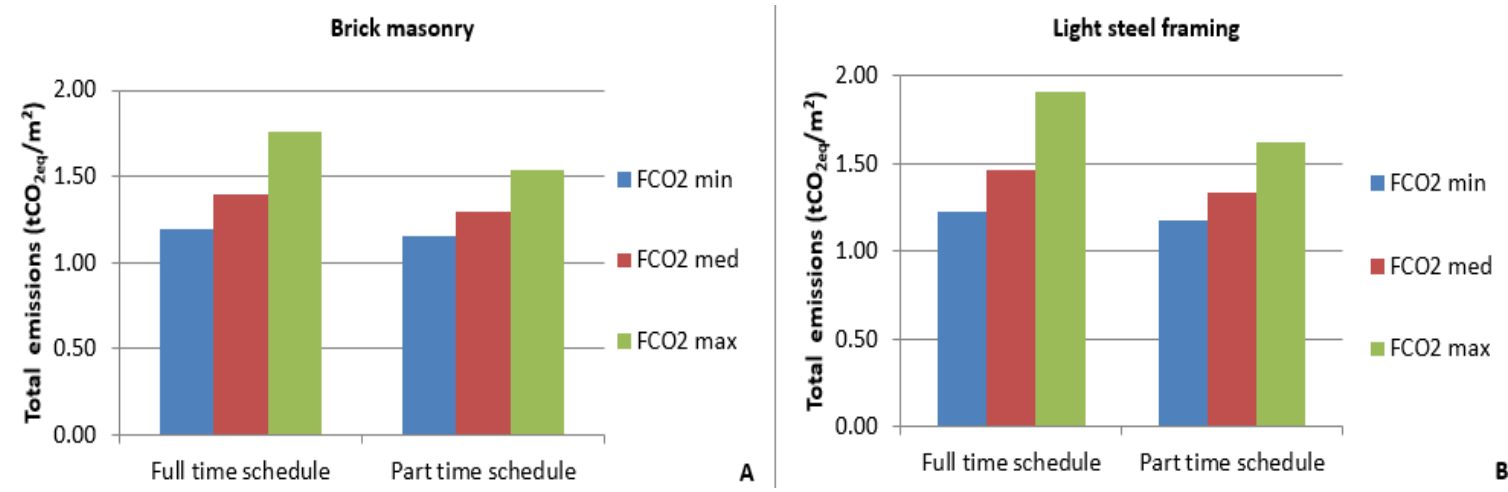
The light steel framing house presented larger values of total $\mathrm{CO}_{2 \mathrm{eq}}$ emissions $\left(\mathrm{ECO}_{2} \mathrm{TOT}\right)$ than the brick masonry house in all scenarios. The brick masonry house presented values ranging from 1.16 $\mathrm{tCO}_{2 \mathrm{eq}} / \mathrm{m}^{2}$ to $1.76 \mathrm{tCO}_{2 \mathrm{eq}} / \mathrm{m}^{2}$ and the light steel framing presented values ranging from 1.17 $\mathrm{tCO}_{2 \mathrm{eq}} / \mathrm{m}^{2}$ to $1.91 \mathrm{tCO}_{2 \mathrm{eq}} / \mathrm{m}^{2}$.

The biggest difference between light steel framing and brick masonry houses $(8 \%)$ was seen in the full time schedule using the $\mathrm{FCO}_{2 \max }$. In this sense, the choice of $\mathrm{FCO}_{2}$ for electricity in this study and in the Brazilian context was an important and critical factor. This is because depending on the $\mathrm{FCO}_{2}$ used there is an increase or decrease in the thermal performance impact on the life cycle carbon emissions.

In Figures 10 and 11, the life cycle carbon emissions for brick masonry and light steel framing houses are presented over time. The black arrows indicate the points on the graph that represent the maintenance phase due to the replacement of materials and components.

The share of each phase in the whole life cycle of the houses for the six scenarios is shown in Figure 12 .

Figure 10 - Life cycle $\mathrm{CO}_{2 \text { eq }}$ emissions over time for ceramic brick masonry house

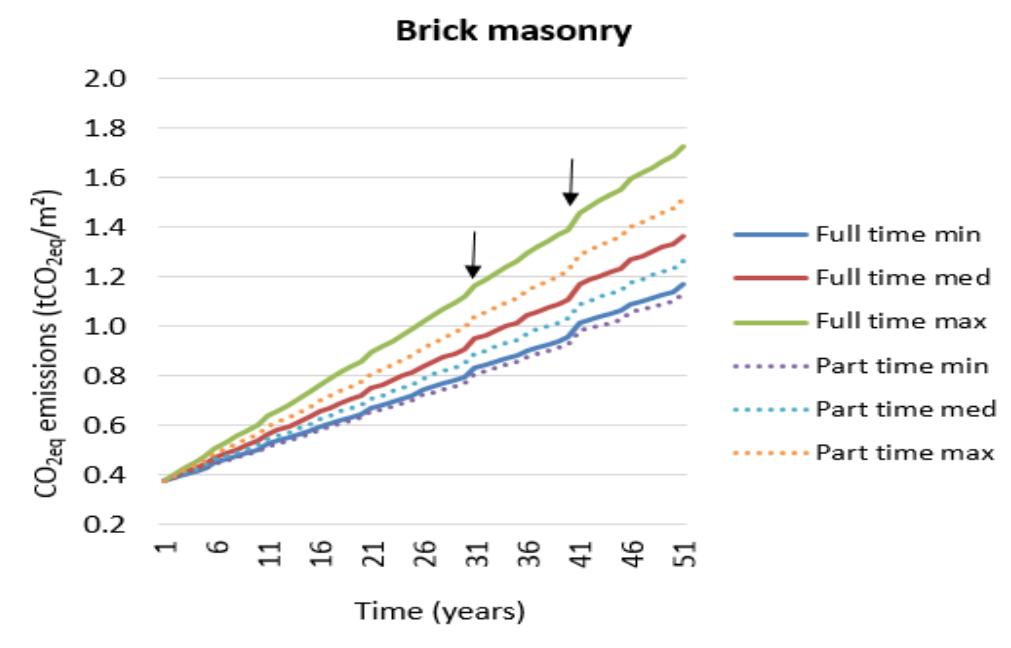

Figure 11 - Life cycle $\mathrm{CO}_{2 \text { eq }}$ emissions over time for light steel framing house

Light steel framing

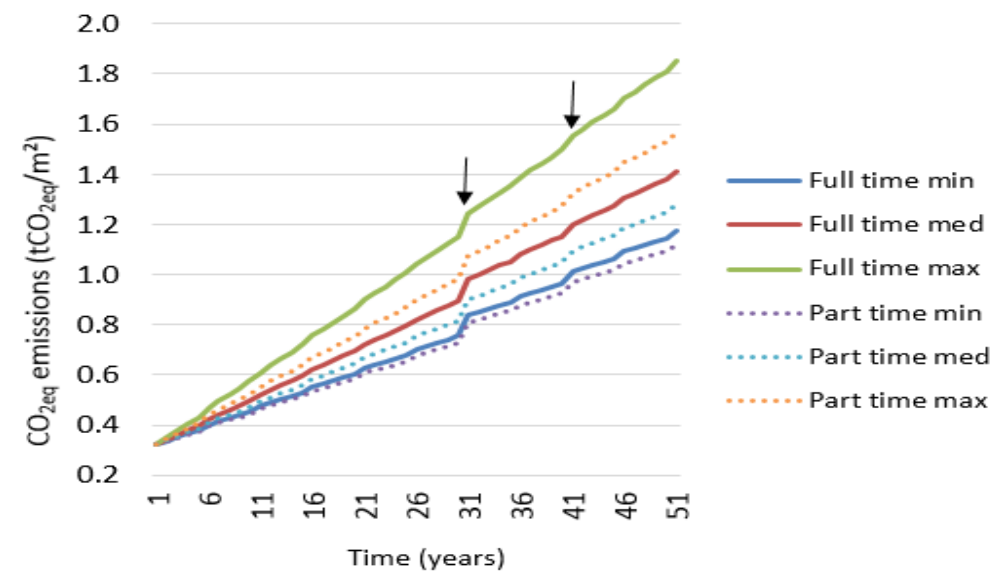


Figure 12 - Share of each phase in the life cycle carbon emissions assessment

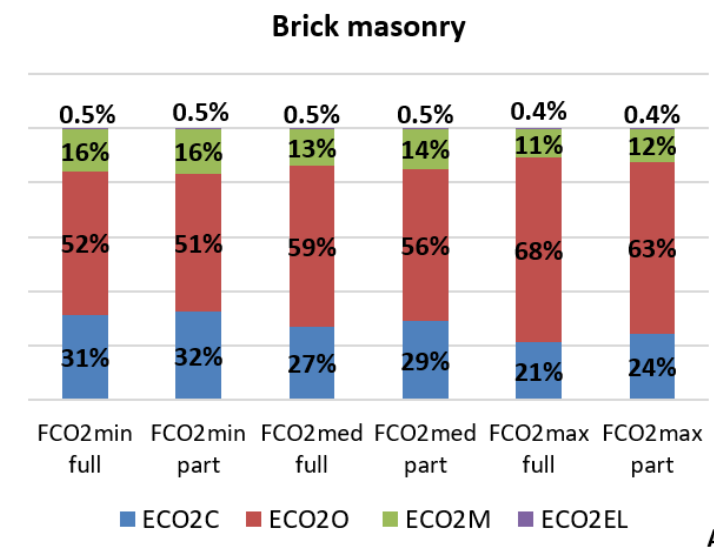

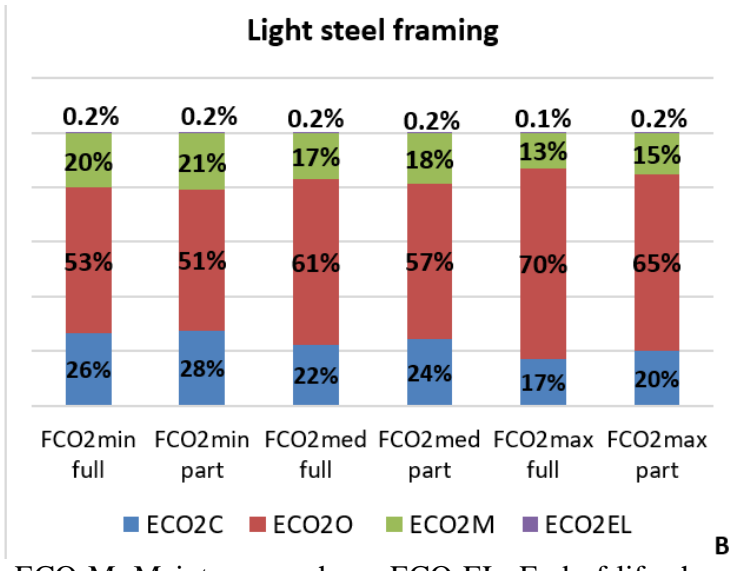

The $\mathrm{CO}_{2 \mathrm{eq}}$ emissions of the operational phase accounted for the highest share of the total building's life cycle, varying from 50 to $70 \%$. In the construction phase, it varied from 20 to $30 \%$, in the maintenance phase, from 11 to $20 \%$, and in the endof-life, it was lower than $1 \%$. It is very important to know which phase has a bigger impact on the carbon life cycle of a building, indicating what the designers should give more attention to during the design stage.

\section{Design guidelines for low carbon social housing}

Finally, based on the results obtained in this study, design guidelines for low carbon social housing were developed (Table 4), as a way to guide designers and builders.

There are different ways for designers to reduce the carbon footprint of a social housing project, as presented in Table 4. However, it is important to define the critical and priority items that result in greater and more effective $\mathrm{CO}_{2 \text { eq }}$ reduction. In this sense, the high ones (in red) deserve a greater attention from designers.

Although not evaluated in this study, bioclimatic architecture principles are very important to consider in the design phase. Features such as crossed ventilation, adequate shading and vegetation, correct openings for heated air outlet, natural lighting, adequate solar orientation and others can help minimize buildings' energy consumption. The use of these strategies related to $\mathrm{CO}_{2 \mathrm{eq}}$ of buildings could be evaluated in future research studies.

\section{Conclusions}

This study used the $\mathrm{LCCO}_{2} \mathrm{~A}$ to investigate $\mathrm{CO}_{2 \text { eq }}$ emissions during the life cycle of two typical social house projects in Brasilia, Brazil. The variables of the study were the external and internal wall systems of the houses, with other parts remaining unchanged. A brick masonry house was compared with a light steel framing system, an industrialized system starting to gain popularity in the country.

The assessment was conducted from a cradle-tograve perspective, including the construction, use (operation and maintenance) and end-of-life phases. The $\mathrm{CO}_{2 \text { eq }}$ emissions from the construction phase were $0.38 \mathrm{tCO}_{2 \mathrm{eq}} / \mathrm{m}^{2}$ for the brick masonry house and $0.32 \mathrm{tCO}_{2 \mathrm{eq}} / \mathrm{m}^{2}$ for the light steel framing house. For the operational phase, the emissions varied from 0.59 to $1.19 \mathrm{tCO}_{2 \mathrm{eq}} / \mathrm{m}^{2}$ for the brick masonry house, and 0.61 to $1.33 \mathrm{tCO}_{2 \mathrm{eq}} / \mathrm{m}^{2}$ for the light steel framing house, corresponding to $50-70 \%$ of the total life cycle emissions. The emissions due to maintenance were $0.19 \mathrm{tCO}_{2 \mathrm{eq}} / \mathrm{m}^{2}$ for the brick masonry, and $0.24 \mathrm{tCO}_{2 \mathrm{eq}} / \mathrm{m}^{2}$ for the light steel framing. The emissions from the end-of-life phase were lower than $1 \%$ for both houses.

Comparing the different systems of the houses (walls, roof, floor, painting and installations), the wall systems presented the biggest share in terms of mass and $\mathrm{CO}_{2 \mathrm{eq}}$ emissions for both houses. The paint system played the biggest role in terms of $\mathrm{CO}_{2 \mathrm{eq}}$ emissions in the maintenance phase.

The brick masonry house presented less total $\mathrm{CO}_{2 \mathrm{eq}}$ emissions than the light steel framing house. The difference between the total emission values varied from $2 \%$ to $8 \%$. This indicates that the light steel framing system for the city of Brasilia would not be a recommendable alternative in terms of $\mathrm{CO}_{2 \mathrm{ec}}$ emissions for the kind of buildings evaluated in this study. 
Table 4 - Design guidelines for low carbon social housing

\begin{tabular}{|c|c|c|c|}
\hline Phases & Stages & Design guidelines & Priority \\
\hline \multirow[t]{2}{*}{ Construction } & $\begin{array}{c}\text { Extraction, processing } \\
\text { of raw materials }\end{array}$ & $\begin{array}{l}\text { Specification of materials, components and systems } \\
\text { with low values of embodied } \mathrm{CO}_{2 \mathrm{eq}} \text { emissions and } \\
\text { adequate thermal performance according to the location } \\
\text { of the building. The wall system was responsible for a } \\
\text { great share of mass and } \mathrm{CO}_{2 \mathrm{eq}} \text { emissions in this phase, } \\
\text { thus deserving special attention. }\end{array}$ & High \\
\hline & Transport & $\begin{array}{l}\text { Specification of materials, components and systems } \\
\text { with lower mass (it is important not to forget the } \\
\text { thermal performance) and located near the construction } \\
\text { site. }\end{array}$ & Low \\
\hline \multirow{4}{*}{ Use } & \multirow{3}{*}{ Operational } & $\begin{array}{l}\text { Electrical equipment (no air conditioning): use of } \\
\text { efficient equipment that consumes less electricity. Use } \\
\text { of label-A equipment as ranked by Procel is } \\
\text { recommended. The electric shower was the equipment } \\
\text { that consumed the greatest share of electricity in social } \\
\text { housing. Therefore, the installation of solar panels to } \\
\text { heat water could be an option. The embodied carbon of } \\
\text { materials and components and end-of-life of solar } \\
\text { panels must be accounted for in the analysis. In a high } \\
\text { FCO }_{2 \text { eq }} \text { scenario for the Brazilian electrical matrix, this } \\
\text { phase becomes more important. }\end{array}$ & $\begin{array}{l}\text { Medium- } \\
\text { High }\end{array}$ \\
\hline & & $\begin{array}{l}\text { Cooking: using natural gas instead of LPG for cooking } \\
\text { could be a good alternative to reduce } \mathrm{CO}_{2 \mathrm{eq}} \text { emissions of } \\
\text { buildings. }\end{array}$ & High \\
\hline & & $\begin{array}{l}\text { Air conditioning: the specification of building systems } \\
\text { with appropriate thermal performance to the building } \\
\text { location is important because it will result in lower } \\
\text { energy consumption by artificially cooling of the } \\
\text { building. This will vary depending on the construction } \\
\text { system adopted, location and climate zones. In a high } \\
\mathrm{FCO}_{2 \mathrm{eq}} \text { scenario for the Brazilian electrical matrix, this } \\
\text { phase becomes more important. }\end{array}$ & $\begin{array}{l}\text { Medium- } \\
\text { High }\end{array}$ \\
\hline & Maintenance & $\begin{array}{l}\text { Specification of materials, components and systems } \\
\text { with higher service life. Bear in mind the correct } \\
\text { maintenance of the systems in order to extend service } \\
\text { life and avoid total replacement of the given material, } \\
\text { component or system. }\end{array}$ & Medium \\
\hline \multirow{3}{*}{ End-of-life } & $\begin{array}{l}\text { Deconstruction/Demo } \\
\text { lition }\end{array}$ & $\begin{array}{l}\text { Specification of systems that can be deconstructed or } \\
\text { removed instead of being demolished. }\end{array}$ & Low \\
\hline & Waste transportation & $\begin{array}{l}\text { Specification of building systems with lower mass and } \\
\text { choice of disposal sites (landfill, recycling plant, } \\
\text { incineration facility, etc.) near the building location. }\end{array}$ & Low \\
\hline & Waste disposal & $\begin{array}{l}\text { Specification of building systems with lower mass to } \\
\text { decrease diesel consumption in disposal activities. }\end{array}$ & Low \\
\hline
\end{tabular}

The results also showed the importance of considering different $\mathrm{CO}_{2 \text { eq }}$ emission factors in the Brazilian context in the operational phase. Finally, based on the results obtained, design guidelines for low carbon social housing were proposed.

It is important to emphasize that some data were taken from foreign literature (mainly for the light steel framing). There is a lack of consolidated Brazilian database of $\mathrm{CO}_{2}$ emissions for building materials. There are only some separate initiatives in some sectors, such as cement and ceramic. When this complete environmental database for Brazilian building materials is published, the authors intend to verify the calculations and the differences in results.

For future research studies, it is recommended to evaluate other environmental aspects, such as water consumption, waste generation and recycling potential of building materials. Other Brazilian systems (both conventional and industrialized ones) 
should be evaluated, such as concrete brick masonry and concrete walls, as well as other Brazilian regions.

\section{References}

ASSOCIAÇÃO BRASILEIRA DE NORMAS TÉCNICAS. NBR 15220-3: desempenho térmico de edificações: parte 3: zoneamento bioclimático brasileiro e diretrizes construtivas para habitações unifamiliares de interesse social. Rio de Janeiro, 2005.

\section{ASSOCIAÇÃO BRASILEIRA DE NORMAS}

TÉCNICAS. NBR 15575-1: edificações habitacionais: desempenho. Rio de Janeiro, 2013.

ATMACA, A.; ATMACA, N. Life Cycle Energy (LCEA) and Carbon Dioxide Emissions $\left(\mathrm{LCCO}_{2} \mathrm{~A}\right)$ Assessment of Two Residential Buildings in Gaziantep, Turkey. Energy and Buildings, v. 102, p. 417-431, 2015.

BERGSMA, G.; SEVENSTER, M. End-of-Life Best Approach for Allocating Recycling Benefits in LCAs of Metal Packaging Delft. CE Delft, Feb. 2013.

BORGES, P. H. R. et al. Estudo Comparativo da Análise de Ciclo de Vida de Concretos Geopoliméricos e de Concretos à Base de Cimento Portland Composto (CP II). Ambiente

Construído, Porto Alegre, v. 14, n. 2, p. 153-168, abr./jun. 2014.

BOVEA, M. D.; POWELL, J. C. Developments in Life Cycle Assessment Applied to Evaluate the Environmental Performance of Construction and Demolition Wastes. Waste Management, v. 50, p. 151-172. 2016.

CABEZA, L. et al. Life Cycle Assessment (LCA) and Life Cycle Energy Analysis (LCEA) of Buildings and the Building Sector: a review. Renewable and Sustainable Energy Reviews, v. 29, p. 394-416, 2014.

CALDAS, L. R. Avaliação do Ciclo de Vida Energético e de Emissões de $\mathrm{CO}_{2}$ de Uma Edificação Habitacional Unifamiliar de Light Steel Framing. Brasília, 2016. Dissertação (Mestrado em Estruturas e Construção Civil) Escola de Engenharia, Universidade de Brasília, Brasília, 2016.

CALDAS, L.; SPOSTO, R. M. Avaliação do Ciclo de Vida Energético (Acve) de Uma Habitação de Light Steel Framing: avaliação do desempenho térmico e simulação computacional. Arquitextos, São Paulo, v. 17, n. 199.04, dez. 2016.
CAMPOS, E. F.; PUNHAGUI, K. R. G.; JOHN, V. M. Emissão de CO2 do Transporte da Madeira Nativa da Amazônia. Ambiente Construído, Porto Alegre, v. 11, n. 2, p. 157-172, abr./jun. 2011.

CARVALHO, M. T. M.; SPOSTO, R. M. Metodologia Para Avaliação da Sustentabilidade de Habitações de Interesse Social Com Foco no Projeto. Ambiente Construído, Porto Alegre, v. 12, n. 1, p. 207-225, jan./mar. 2012.

CHAU, C. K.; LEUNG, T. M.; NG, W. Y. Review on Life Cycle Assessment, Life Cycle Energy Assessment and Life Cycle Carbon Emissions Assessment on buildings. Applied Energy, v. 143, p. 395-413. 2015.

\section{DEUTSCHE ROCKWOOL. Stone Wool Insulating Materials in the Medium Bulk Density Range. Environmental Product Declaration. Institute Bauen und Umwelt e.V. 2012.}

INSTITUTO AÇO BRASIL. Relatório de Sustentabilidade: o aço e a economia circular. 2016. Available at:

<http://www.acobrasil.org.br/sustentabilidade/> Assessed at: 12 Jan. 2017.

INTERGOVERNMENTAL PANEL ON CLIMATE CHANGE. Guidelines for National Greenhouse Gas Inventories, v. 2-Energy. 2006.

INTERGOVERNMENTAL PANEL ON CLIMATE CHANGE. Climate Change 2013: the physical science basis, contribution of working group i to the fifth assessment report of the intergovern mental panel on climate change. Cambridge: Cambridge University Press, 2013.

INTERNATIONAL ORGANIZATION FOR STANDARDIZATION. ISO 14040:

Environmental Management: life cycle assessment: principles and framework. Geneva, 2006.

\section{KNAUF. Aquapannel. Cement Board} Indoor/Outdoor. Environmental Product Declaration. Institute Bauen und Umwelt e.V. 2013a.

KNAUF. Gypsum fibreboards. Environmental Product Declaration. Institute Bauen und Umwelt e.V. $2013 b$.

LIMA, E. C. Habitação Popular Eficiente: obras. Téchne, São Paulo, v. 231, jun. 2016. 
LUCON, O. et al. 2014: Buildings. In: Climate Change 2014: Mitigation of Climate Change. Contribution of Working Group III to the Fifth Assessment Report of the Intergovernmental Panel on Climate Change. Cambridge: Cambridge University Press, 2014.

MINISTÉRIO DA CIÊNCIA E TECNOLOGIA E INOVAÇÃO. Fatores de Emissão de $\mathrm{CO}_{2}$ do Sistema Interligado Nacional do Brasil. Available at:

<http://www.mct.gov.br/index.php/content/view/3 21144.html >. Access at: 04 Sep. 2016.

MINISTÉRIO DO MEIO AMBIENTE. Inventário Nacional de Emissões Atmosféricas por Veículos Automotores Rodoviários. Brasília, 2013.

MINISTÉRIO DE MINAS E ENERGIA. Balanço Energético Nacional. Relatório do Ano de 2015, Brasília, 2016.

PASSUELLO, A. C. B. et al. Aplicação da Avaliação do Ciclo de Vida na Análise de Impactos Ambientais de Materiais de Construção Inovadores: estudo de caso da pegada de carbono de clínqueres alternativos. Ambiente Construído, Porto Alegre, v. 14, n. 4, p. 7-20, out./dez. 2014.

PAULSEN, J.; SPOSTO, R. A Life Cycle Energy Analysis of Social Housing in Brazil: case study for the program MY HOUSE MY LIFE. Energy and Buildings, v. 57, p. 95-102, 2013.
PEDROSO, G. M. Avaliação de Ciclo de Vida Energético (ACVE) de Sistemas de Vedação de Habitações. Brasílai, 2015. Tese (Doutorado em Estruturas e Construção Civil) - Escola de Engenharia, Universidade de Brasília, Brasília, 2015.

PEREIRA, I. M.; ASSIS, E. S. Avaliação de Modelos de Índices Adaptativos Para Uso no Projeto Arquitetônico Bioclimático. Ambiente Construído, Porto Alegre, v. 10, n. 1, p. 31-51, jan./mar. 2010.

SAADE, M. R. M. et al. Material Eco-Efficiency Indicators for Brazilian Buildings. Smart and Sustainable Built Environment, v. 3, n. 11, p. 54-71, 2014.

SANTORO, J. F.; KRIPKA, M. Determinação das Emissões de Dióxido de Carbono das Matérias Primas do Concreto Produzido na Região Norte do Rio Grande do Sul. Ambiente Construído, Porto Alegre. v. 16, n. 2, p. 35-49, abr./jun. 2016.

SOUZA, D. M. et al. Comparative Life Cycle Assessment of Ceramic Brick, Concrete Brick and Cast-in-Place Reinforced Concrete Exterior Walls. Journal of Cleaner Production, v. 137, p. 70-82, 2016.

VOTORANTIM CIMENTOS. Cements CP II E 40, CP III-40 RS and CP V-ARI (bulk form)

Available at:

<http://www.environdec.com/en/Detail/epd895>. Access at: 26 sep. 2016.

\section{Lucas Rosse Caldas}

Program of Civil Engineering | Federal University of Rio de Janeiro | Cidade Universitária, Centro de Tecnologia, Bloco B, Itha do Fundão | Rio de Janeiro - RJ - Brazil | CEP 21945-970 | Tel.: +55 (62) 99672-7202 | E-mail: Irc.ambiental@gmail.com

\section{Júlia Santiago de Matos Monteiro Lira}

Dept. of Civil and Environmental Engineering | University of Brasília | Faculdade de Tecnologia, SG-12 Mestrado em Estruturas e Construção Civil, Campus Universitário UnB Darcy Ribeiro, Asa Norte | Brasília -DF - Brazil | CEP 70910-900 | Tel.: +55 (61) $98290-8666$ | E-mail: juliasanttiago@gmail.com

Pedro Corrêa de Melo

Dept. of Civil and Environmental Engineering | University of Brasília | Tel.: +55 (61) 99905-8321 | E-mail: pedro.meloc@gmail.com

Rosa Maria Sposto

Dept. of Civil and Environmental Engineering | University of Brasília | Tel.: +55 (61) 3274-1517 | E-mail: rmsposto@unb.br

\section{Revista Ambiente Construído}

Associação Nacional de Tecnologia do Ambiente Construído

Av. Osvaldo Aranha, $99-3^{\circ}$ andar, Centro

Porto Alegre - RS - Brasil

CEP 90035-190

Telefone: +55 (51) 3308-4084

Fax: +55 (51) 3308-4054

www.seer.ufrgs.br/ambienteconstruido

E-mail: ambienteconstruido@ufrgs.br 